HANNO BRAND

Assistant Ghent University

\title{
URBAN ELITES AND CENTRAL GOVERNMENT; CO-OPERATION OR ANTAGONISM? THE CASE OF LEIDEN AT THE END OF THE MIDDLE AGES
}

In his influential book «Coercion, capital and European states» Tilly pointed out that the effectiveness of the opposition of towns against the process of state formation was closely connected with the size of urban centers and their political and economic power ${ }^{1}$. Large cities with a flowering economy and a considerable impact on the surrounding countryside, fiscally, economically and politically, turned out to be of great importance for state building princes. In cities where huge amounts of capital were accumulated, wealth could easily be tapped by levying all kinds of taxes and aids, needed for financing wars, the installation of central institutions and the salaries for the fast growing number of governmental officials. By becoming more dependant on the financial resources of cities, magistrates, who jealously protected the autonomy of the town and their own powerful positions, proved to be tough negotiators, especially when they were assembled in representative institutions. Princes with urgent needs found it very difficult to deal with their powerful subjects. Large cities with strong market positions frustrated the ambitious plans of centralizing princes and slowed down the state formation process. Only when economic conditions deteriorated, cities could more easily be submitted to a central power.

When Philip the Good annexed the Dutch coastal areas, his main interest was not so much focused on the rather small cities as such, but mainly on the promising economic potential of the cluster of towns in Holland and Zealand. Because of a well developed and dense transport network and the fact that the protocapitalistic structure of the surrounding countryside supported the economic and demographic expansion of the main urban centers, it was justified to consider the new acquired territories as «terres de promission $»^{2}$.

1. Ch. TILLY, Coercion, capital and European states 990-1990, Oxford, 1990, pp. 58-60, 68-70, 86. See also W.P. BLOCKMANS, Voracious states and obstructing cities. An aspect of state formation in pre-industrial Europe, in History and theory 18, 1989, pp. 733-745.

2. A.G. JONGKEES, La Hollande Bourguignonne: son intérêt pour les ducs Valois, in E.O. VAN DER WERFF, C.A.A. LINSSEN, B. EBELS-HOVING (ed.), Burgundica et 
In many ways Leiden can be taken as a typical exponent of developments in the county under Burgundian rule. Compared to Ghent or Bruges, Leiden was not very large, nor very powerful. At the advent of the reign of Philip the Good the city counted about 5.000 or 6.000 inhabitants. At the end of the 15 th century their number had increased to over $14.000^{3}$. By then Leiden was for some decades the largest town in Holland. Its demographic expansion was closely connected with the rapid rise of the textile industry. Starting as a rather modest industrial sector halfway the 14th century, it became the spine of the cities welfare and attracted several thousands of rural dwellers and unemployed textile labourers from other cities. Especially the third quarter of the 15 th century is regarded as the highlight of the Leiden textile industry. The very favourable conditions in Holland at that time were a consequence of Philip the Good's careful policies, characterized by the absence of wars, internal peace and a stable mint policy ${ }^{4}$. The situation altered drastically during the reign of Charles the Bold and Maximilian of Austria. Their war efforts, an almost rigid centralizing policy and unfortunate mint policy damaged the already worsened economic conditions even more. At the end of the century many cities in the Low Countries, among which Leiden, faced bankruptcy and could only be saved by the farreaching intervention of Philip the Fair and his skilled officials 5 .

Nevertheless, Leiden textile industry kept on producing high quality cloth in considerable amount and employed not only labourers living in the city, but also many rural families on the surrounding countryside. However, Jansma already made clear that the city's economic influence was not tumed into large scale political and fiscal domination. Although the area in which the Leiden magistrate was allowed to levy taxes on consumable goods was enlarged several times in the

varia, Hilversum, 1990, p. 154. IDEM, Vorming Bourgongdische staat, in Ibidem, p. 225. With regard to the protocapitalistic structure of the countryside see J.L. VAN ZANDEN, Arbeid tijdens het handelskapitalisme. Opkomst en neergang van de Hollandse economie 1350-1850, Bergen, 1991, pp. 31-46.

3. DE.H.de BOER, Die politische Elites Leidensam Endedes Mittelalters, eine Zwischenbilanz, in H. SCHILING, H.A. DIEDERIKS, Eliten in den Niederlanden und in Nordwest Deutschland, Köln, Wien, 1985, p. 88. DEM, Leiden in de middeleeuwen, in J.K.S. MOES, B.M.A. DE VRIES, Stof uit het Leidse verleden. Zeven eeuwen textielnijverheid Utrecht, 1990, pp. 37-39.

4. L. NOORDEGRAAF, Hollands welvaren? Levensstandaard in Holland 1450-1630, Bergen, 1985, pp. 76, 171-173. D.E.H. de BOER, Graafen grafiek. Sociale en economische ontwikkelingen in het laat-middeleeuwse "Noordholland tussen ca. 1345 en 1415, Leiden, 1978, pp.144-148, 166.N.W.POSTHUMUS, De Geschiedenis van de Leidsche lakenindustrie (veertiende tot zestiende eeuw), The Hague, 1908, pp. 187-202, 374-375. W.P. BLOCKMANS, W. PREVENIER, In de ban van Bourgondië, Houten, 1988, pp. 93-118.

5. R.VANUYTVEN, Politiek en economie. De crisis in de late 15 de eeuw in de Nederlanden, in Belgisch tijdschrift voor filologie en geschiedenis 53, 1975, pp. 1143-1145. NOORDEGRAAF, Hollands welvaren?, pp. 28-34, 75-78, 118-123, 143. H.G. HAMAKER, De stad Leiden in staat van faillissement, in Verslagen en mededelingen Oud-vaderlandsch recht 3, 1893-1895, pp. 181-207. W. DOWNER, De financiële toestand van Leiden omstreeks 1500, 1951 (unpublished lecture, available at the Leiden municipal archives), pp. 8-14. 
course of thefifteenth century, it did not reach further then 500 rods form the citywalls about 1500. Castles in the neighbourhood of the city posed no threat whatsoever against the troops of the sovereign when he city was put to siege in 1420 and $1481^{6}$. It means that Leiden did not fit entirely in the model Tilly sketched of urban bastions against centralizing princes. The aim of this article is trying to show to what extent Leiden was turned into an agent of the Burgundian policy. The scope of the paper is limited to the political scene and establishes what strategies princes developed to undermine the urban autonomy.

\section{Rebellion and state intervention}

The centralizing policy of the Burgundians met serious resistance in the large cities of the Southern Netherlands. Between 1436 and 149011 major urban risings are to be counted of which three in Bruges (1436-1438, 1485 and 1488$1490)$ and four in Ghent (1447-1453, 1467, 1485, 1487-1492). Other risings occured in Liege, Dinant and Malines. In the Northern Low Countries Utrecht and several cities in the county of Holland, among which Leiden, rebelled between 1480 and 1483. In all cases the towns were submitted by force, sometimes even destroyed, and deprived of privileges which guaranteed their political autonomy ${ }^{7}$. As Tilly pointed out, war became a state monopoly not only in order to defend the new territorial borders but also to repress internal unrest. The monopoly of violence was reached by denying the use of arms and other means of coercion by all subjects. Princes gradually succeeded in disarming their subjects by issuing laws forbidding the carrying of weapons. They also tried to prevent the escalation of feuds between families by submitting their quarrels to urban or even state courts ${ }^{8}$.

Although the position of the Burgundian princes was never seriously challenged in Leiden, many of the above mentioned aspects of the state formation process are to be found there.In 1434, the very first year of the reign of Philip the Good as count of Holland, a new issued ordination forbidding the carrying of armours and long knives in public formed the direct cause of an attack against the sheriff, the counts representative, and several of his helpers by members of a leading family called Van Berendrecht. The Van Berendrechters and a group of supporters had provoked the sheriff by refusing to take off their armours and by parading armed through the mainstreet of the city. A fight broke out and the sheriff had

6. TS. JANSMA, Het economisch overwicht van de laatmiddeleeuwsche stad ten aanzien van haar agrarisch ommeland in het bijzonder toegelicht met de verhouding tussen Leiden en Rijnland, in IDEM, Tekst en uitleg, The Hague, 1974, pp. 44-50.

7. W.P. BLOCKMANS, Alternatives to monarchal centralisation: the great tradition of revolt in Flanders and Brabant, in H. KOENIGSBERGER, Republiken und Republikanismus in der frühen Neuzeit (Schriften der Historischen Kollegs Kolloquien 11), Oldenburg, s.d., pp. 151-153.IDEM, La répression de révoltes urbaines comme méthode de centralisation dans les Pays-Bas bourguignons, in Publication du Centre européen d'études bourguignonnes (XIVe-XVIe s.) 28, 1988, pp. 7-9.

8. TILLY, Coercion, pp. 68-70. 
to be protected by some members of the city council. One of his deputees was wounded in the face with a knive ${ }^{9}$. The hidden cause behind this fight was connected with the partystrife in Holland, known as the «Hoekse en Kabeljauwse twisten ». Struggles between both factions had already affected political life in Leiden since 1350 . In 1420 members of the Hoeks party took over Leiden by force, in order to turn the city into a bastion against John of Bavaria, the new count of Holland who had taken sides with the Kabeljauws. After laying siege to the city the Hoeks were repelled from political power. From that moment on a Kabeljauws majority controlled urban politics ${ }^{10}$. Nevertheless tensions between both factions remained and must probably be connected with the murder of John of Bavaria in 1425. On january sixth the duke died of what is believed the consequences of poisining. The main suspect, Jan van Vliet, confessed he obtained the poison from some English merchants who maintained contacts with banished members of the Hoeks faction. By lubricating the poison on the pages of the prayer book of the duke, who apparently had the nasty habit of licking his fingers before turning the pages, he eventually killed him. Besides Jan van Vliet who was put to death, the Leidener Hoeks Pieter Butewech and his brother Dirk de Bruin were thought to be accomplices. Because of that members of the knighthood and representatives of the main cities of Holland requested expulsion of both Leydeners from the Zoen or Treaty of Delft signed in 1428, which regulated relations and governmental competencies between Philip the Good and Jaqueline of Bavaria11.

Some time laterDirk de Bruin was killed by members of the Kabeljauws faction who were out for revenge. To prevent further escalation, the duke forbade other attempts of revenge by members and friends of the victim's family. However, during the fight in Leiden, the Van Berendrecht family made allusions to the murder of their uncle Dirk de Bruin and broke by doing that the law ${ }^{12}$. The reason for the attack on the sheriff becomes more clearer now. Being the duke's representative, the sheriffembodied the central government which had forbidden the carrying of weapons and by doing that hindered the ancient right of revenge and feud. In that way the Van Berendrecht family, who were members of the anti-Burgundian Hoeks faction, was forced to accept regulations of a government they did not support and that maintained the actual balance of power within the city.

9. Leiden, Municipal archives (further quoted as GAL), Oud Rechterlijk Archief(ORA), inv. 4A Correctieboek 1434-1448, pp. 3-12.

10. FJ.W. VAN KAN, Sleutels tot de macht, Hilversum, 1988, pp. 162-165. A.J. BRAND, Twistende Leidenaars. Verkenningen naar het voorkomen van partij en factie, clan en kerngezin aan de hand van drie oproeren in een Hollandse stad in de vijftiende eeuw, in J.W. MARSILE (ed.), Bloedwraak, partijstrijd en pacificatie in laat-middeleeuws Holland, Hilversum, 1990, pp. 84-87.

11. H.PH. JANSEN, Hoekse en Kabeljauwse twisten, Bussum, 1966, pp. 67-69. T.S. JANSMA, Raad-en rekenkamer in Holland en Zeeland tijdens hertog Philips van Bourgondië, Utrecht, 1932, pp. 200-203, Bijlage A. Bronnen voor de geschiedenis der dagvaarten van de Staten en steden van Holland voor 1544. Deel 1: 1276-1433, edit. W. PREVENIER, J.G. SMIT, 's-Gravenhage, 1987, p. 713.

12. GAL. ORA inv. 4A Correctieboek 1434-1448, pp. 10-11. 
Indeed, peace and order were restored after the duke ordered his stadholder, Huge of Lannoy, lord of Santes, to punish the rioters. Although the acts of the Van Berendrechters in fact demanded death penalty and seizure of their possessions, the duke showed his benevolence and suggested moderate punishment in order to maintain peace in the county. Convictions did not reach further than banishments and forced pilgrimages ${ }^{13}$. This approach characterizes the policy of the Burgundian duke in the early years of his reign. Also during risings of fullers in Ghent between 1423 and 1427 the duke was equally reluctant, hoping that this attitude would prevent further unrest among the textile workers who were out to alter the balance of power in that city ${ }^{14}$. As in Ghent, the duke supported the present government by thanking his sheriff and the members of the city council for maintaining the ducal laws.

Ten years later Philip the Good took a somewhat firmer point of view against rebelling members of the Hoeks faction in Leiden. The struggle was a consequence of the unfortunate policy of stadholder William of Lalaing, who openly supported the Hoeks by appointing them in all kinds of lucrative functions not only in Leiden, but also in Amsterdam and Harlem. Agitation between Hoeks and Kabeljauws had also roused because of the irregular financial policy of Hoeks treasurers in several towns, the dissatisfaction with the height of the indemnification payments concerning the peace treaty with Copenhagen in 1441 and the levying of aids. In 1444 riots broke out in Harlem which demanded the attention of the duke's wife Isabella of Portugal. While leaving the city she had to suffer a humiliating search of her bagage, in which Harlem Kabeljauws suspected the stadholder to be hidden. After appointing several Hoeks magistrates in Amsterdam, William of Lalaing provoked enormous tension between both factions there, resulting in heavy fights in the course of 1444 and 144515. In Leiden riots broke out in 1445, when it became clear that the Hoeks schout Floris van Boschhuijsen had appropriated money out of a bastards legacy of which half belonged to the duke. He was replaced by the Kabeljauw Simon Vrederick Willemszn. who assumed office the day before Pentecoste. The deputee and brother in law of the former sheriff, having great difficulty with accepting the shift of power, provoked Simon Vrederick Willemszn. The same night by almost running into him deliberately. The provocation was seen as a crime against the central govermment for which he was eventually banished for life.

The confrontation caused serious fights within the city on june 17th. which ended with the withdrawal of the Hoeks assailants. Because of the clash between both factions, members of the council in Holland travelled on high speed to Leiden to investigate the causes of the riots. They also ordered the installation of two captains who had to restore and maintain law and order. Their presence,

13. GAL. ORA inv. 4A Correctieboek 1434-1448, p. 11.

14. M. BOONE, H. BRAND, Vollersoproeren en collectieve actie in Gent en Leiden (14de15 de eeuw), in Tijdschrift voor Sociale Geschiedenis (in print).

15. T. OVERSTEEGEN, Hoeken aan de macht tijdens stadhouder Willem van Lalaing, 1440-1445, in J.W. MARSLJE (ed.), Bloedwraak, partijstrijd en pacificatie in laatmiddeleeuws Holland, Hilversum, 1990, pp. 107-115. 
however, could not prevent the outbreak of new fights between Hoeks and Kabeljauws the first of july. The instigators were once again the Hoeks. The Kabeljauws accompanied by the president of the council mr. Gosewijn de Wilde tried to prevent further escalation by attempting to start negotiations. The Kabeljauws made out a majority, especially when the president asked for the support of 200 soldiers from out of town. However, the leaders of the Hoeks, the present burghomasters Willem van Berendrecht and Floris van Zijl refused to give in and encouraged their followers to attack. An unexpected coun terassault of the Kabeljauws broke in very short time all resistance. After the Hoeks surrendered 112 prisoners were made, among whom the burghomaster Van Berendrecht. Many others managed to escape but were to be arrested rather quickly.

Initially the duke took severe measurements. An army lead by Aernt van Egmond was garrisoned in Leiden for several months. The council of Holland convicted three main instigators to death. Many others were banished varying from one year to a lifetime. Fines varied from $4 \mathrm{lb}$. Hollands to 400 pounds. Sentences concerning forced pilgrimages were hardly pronounced. Nevertheless, within two years the duke started to grant amnesty to many exiles and already in 1449 ageneral pardon was announced. The next year most convicted Hoeks were to be found in the city ${ }^{16}$. Again the duke, whose position was in fact never questioned, showed some benevolence in order to prevent that deep rooted frustration became a threat to peace in the county.

In january 1481 Leiden was occupied by an army of Hoeks, mainly made out of victims of a succesful Kabeljauws coup in 1479 who were driven into exile since then. They were supported by soldiers from Guelders and Utrecht headed by the condotierri Reinier van Broekhuizen and Willem van Zuijlen Nyevelt. The attack resulted into the replacement of the present Kabeljauws magistrate, which was openly supported by Maximilian. Nonetheless, the Hoeks created a new regime and occupied the city for more than three months. Although the Hoeks on several occasions requested legitimation of the new political order, their attempts met severe resistance. The Hadsburg emperor would never allow a Hoeks regime to remain that gained power with help of troops from Utrecht and Guelders, which already formed a threat to his territories. Furthermore the Kalbejauws tried to convince Maximilian of the risk that Leiden would be turned into a Hoeks bastion from which coups in other cities could be planned. It would mean large scale rebellion and a real threat to Maximilians position. Already the situation in Gouda, Schoonhoven and Dordrecht, cities who traditionally chose sides with the Hoeks, proved to be quite worrysome. Fast and firm action seemed to be needed. Maximilian gave order to his stadholder Joost van Lalaing to assemble an army that would put siege to the city. Despite some Hoeks successes when troops clashed in the neighbourhood of Alphen, the Hoeks proved not to be able to withstand the siege and surrendered on april 15th.

16. Based on R. LADAN, A. NETIV, Leiden 1445. Hoeken in verzet, in Leids Jaarboekje, 1988, pp. 25-39. BRAND, Twistende Leidenaars, pp. 87-91. 
Probably with regard to the very tense situation in several other cities in Holland, Maximilian did not spare the rebellions. Already during the siege two captured Hoeks were put to death by Joost van Lalaing. When Maximilian entered the city on april 19th seven others suffered the same fate. The majority of the emprisoned Hoeks were sentenced to lifetime exile and seizure of their possessions. Furthermore the city was sentenced to a 50.000 pounds fine, to be payed for $2 / 3$ by the city and $1 / 3$ by the inhabitants, with exception of the captured Kabeljauws during the Hoeks occupation. The emperor «reserved 20 prisoners to deal with them as he liked. They were eventually released after paying a considerable ransom ${ }^{17}$. The Hoeks occupation in 1481 turned out to be the last outburst of large scale factionstrife in Leiden. Contrasts between Hoeks and Kabeljauws slowly faded away together with the resistance against the centralizing policy of the Burgundians and Habsburgers.

\section{Interference in city politics}

An important aspect of the centralizing strategies of the Burgundian dukes was the alteration of urban political structures after rebelling cities had been submitted to central power. Privileges that guaranteed urban autonomy were very often withdrawn. In fact the central government grabbed the opportunity to dismantle political networks making out obstacles to the state building process or changed these in such way that local rulers became more co-operative. According to Blockmans and Prevenier the Burgundian dukes consciously tried to turn rather autonomous urban governors into agents of their centralizing policy ${ }^{18}$. However, they never meant to eliminate the existing political structures because these were needed to maintain law and order and also moulded local social and economic policies. Elias held the opinion that princes took sides with the underdog, generally rivals of those who were in power, in order to prevent complete superiority of autonomous ruling elites. If the latter were the case the position of the central government would have been undermined or even become superfluous because people always would turn to those who effectively were in power ${ }^{19}$. Although many objections have been formulated against Elias' sometimes superficial approach because of lack of well based comparisons and his insufficient knowledge of specific circumstances, both points of view can be used as a touchstone for the Leiden situation ${ }^{20}$.

17. Based on MJ. VAN GENT, Hoeken en Kabeljauwen 1477-1481, een nieuw overzicht, in Leids Jaarboekje, 1987, pp. 35-62. JANSEN, Twisten, pp.89-93. BRAND, Twistende Leidenaars, pp. 91-94.

18. BLOCKMANS, PREVENJER, In de ban van Bourgondië, pp. 85-88.

19. N. ELIAS, Het civilisatieproces. Sociogenetische en psychogenetische onderzoekingen, Utrecht, 1987, pp. 554-557.

20. See for some critical comments W.P. BLOCKMANS, Princes conquérants et bourgeois calculateurs. Le poids des réseaux urbains dans la formation des Etats, in N.BULST, J.-Ph. GENET, La ville, La bourgeoisie et la genèse de l'Etat moderne (XII ${ }^{e}$ XVIII siècles), Paris, 1988 , p. 168. 
Very specific for the Dutch situation was the existence of so called «vroedschappen »; councils designed at the end of the fourteenth century to advise the daily governing circle made out of sheriff, burghomasters and aldermen. The majority of functions of the «gerecht» or daily administration were assigned to members of the Vroedschap, relatives of factionmembers. Jansen stated that the vroedschappen started to close ranks by co-optation from 1425 on, the year that Philip the Good assumed his ruling tasks in Holland ${ }^{21}$. In fact that kind of election procedure already existed about 1400 and does not seem to be the only explanation for the enclosure of the ranks of vroedschap members against newcomers halfway the $1420^{22}$. It seems more accurate to say that Hoeks could be prevented to enter the vroedschap after John of Bavaria layed siege to Leiden in 1420 and forced all Hoeks out of leading positions within the town. He was able to do so by granting the nomination right of daily administrators to the victorious Kabeljauws. As did his predecessors, the duke rented this right to some rich burghers, mostly supporters of his policy, for a considerable amount of money. These farmers were able to build up an enormous authority within the city and assigned most functions again to relatives and faction members. In that way a mechanism was created that enabled the Kabeljauws to force rivalling Hoeks into a political minority, although it turned out in 1434 that some Hoeks had managed to become co-farmers of the nomination right of aldermen ${ }^{23}$. In Leiden, the election of burghomasters was the exclusive right of the vroedschap, dominated by Kabeljauws since 1420, while the sheriff rented his office directly from the duke himself. By using this procedure, the dukes created a network that in general supported the Bavarian and Burgundian political option.

Nonetheless, in 1434 the new count of Holland, Philip the Good, abolished the farming procedure in Leiden ${ }^{24}$. It is tempting to interpret this measure as one of his many attempts to enforce a political equilibrium of Hoeks and Kabeljauws in order to prevent further outbursts of partystrife. One should however take into account that this privilege was issued at request of the townmagistrate, which was dominated by Kabeljauws. By abolishing the farming system, the duke lost undoubtedly some very powerful pawns, buth at the same time supported the Kabeljauw faction, for the Leiden magistrate returned to the procedure of cooptation which was much to the advantage of the majority of rulers, being Kabeljauws. One of the very few Hoeks who was capable to obtain a seat in the magistrate in the course of the 1430 's was Willem van Berendrecht, the only member of his family who during the riot of 1434 made serious efforts to calm down high

21. H.P.H.JANSEN, Modernization ofgovernment: the advent of Philip the Goodin Holland, in Bijdragen en Mededelingen betreffende de geschiedenis der Nederlanden 95/2 (1980), pp. 363-364.

22. VAN KAN, Sleutels tot de macht, pp. 99-105.

23. See for this system J.W.MARSILJE, Het financiële beleid van Leiden in de Laat-Beierse en Bourgondische periode ca. 1390-1477, Hilversum, 1985, pp. 39-49. Faction membership of Hoeks in 1434 is based on VAN KAN, Sleutels tot de macht, pp. 310-332.

24. MARSILJE, Het financiële beleid, pp. 43-44. 
running emotions ${ }^{25}$. The stadholder was permitted to grant him pardon for his remarkable role in the quarrel. Apparently his performance was rewarded with political recognition. However, as mentioned before, in 1445 he belonged to the leaders of the Hoeks resurrection and was convicted for his complicity ${ }^{26}$.

The political unrest in 1444-1445 had put an end to the career of Willem van Lalaing and the political domination of the Hoeks in Leiden. Many Hoeks were driven into exile which gave the Kabeljauws the opportunity to regain their former positions within the magistrate ${ }^{27}$. Dissatisfaction with the existing balance of power forced members of the Hoeks faction in 1449 to launch a new attempt to overthrow the Leiden magistrate. That year representatives from Leiden were confronted with the rumour that some Hoeks had offered a large amount of money to the duke, in exchange for his permission to «reorganize» the daily administration. The magistrate was only able to prevent this coup by asking the dukefor the installation of an election council of fourty members, to which Philip agreed only after he was offered the sum of $1824 \mathrm{lb} 8 \mathrm{sh}^{28}$. In this case the duke profited from tensions between both parties. The election council of Fourty or "Veertigraad » had no other obligations then electing 16 candidate aldermen out of which the duke would nominate out the needed 8 officials. Theoretically the duke should have been able to reach some kind of equilibrium between Hoeks and Kabeljauws. A considerable majority of council members was however Kabeljauws and once again the Hoeks were poorly represented in all political institutions for the years to come ${ }^{29}$. The privilege of the council of Fourty had to be renewed in 1452 and 1462, but only after the magistrate had agreed on paying considerable aids ${ }^{30}$.

While Philip the Good respected existing privileges and remained in general loyal to his political option in supporting the Kabeljauws magistrate, his son Charles the Bold turned out to be less reluctant. On several occasions he blackmailed the Leiden magistrate by pointing out that rich Hoeks factionmembers were prepared to allow him extensive loans in exchange for political power. Furthermore he refused to renew the privilege of Fourty in 1472. His motives were clear. By strenghtening his grip on the appointment of aldermen he undermined the Kabeljauws domination. Between 1472 and 1478 a considerable number of Hoeks made their way into the daily administration and vroedschap. Since membership of the council lasted a lifetime, Hoeks representation in Leiden politics seemed to be assured. Charles the Bold's disrespect for urban privileges became

25. GAL. ORA inv. 4A Correctieboek 1434-1448, p. 8.

26. LADAN, NETIV, Leiden 1445, p. 37.

27. LADAN, NETIV, Leiden 1445, pp. 39-40. See for the loss of political influence of the Hoeks M.J.van GENT, De Hoekse factie in Leiden ca. 1445-1490. Het verhaal van de verliezers, in J.W. MARSILJE (ed.), Bloedwraak, partijstrijd en pacificatie in laat-middeleeuws Holland, Hilversum, 1990, pp. 123-126.

28. MARSULJE, Het financiële beleid, pp. 59-62, 257.

29. VAN GENT, De Hoekse factie in Leiden, pp. 124-126.

30. MARSIJE, Het financiële beleid, pp. 59, 298-299. 
particularly clear in 1475 when he tried to surpass the vroedschap's right to elect the burghomasters and wanted to force his own Hoeks nominees upon the city ${ }^{31}$. His attempt failed but relations between the duke and the town magistrate of course worsened.

During the confused period after the duke's sudden death in 1477 representatives of the knighthood and large cities from the Burgundian territories within the Low Countries succeeded in forcing his daughter and successor Maria to undo the excesses of her father's centralizing policy. One of the issues dealt with in the separate Privilege for Holland and Zealand, concerned the restoration of the election councils in most cities, among which Leiden ${ }^{32}$. There, even contradictions between Hoeks and Kabeljauws were put aside in order to protect and restore the political autonomy of the city. On january 31rst 1477101 nobles and eminent burghers from Leiden swore to put an end to all discord and promised to govern the city in good order and co-operation. As a consequence both factions had to be equally represented in all governing bodies, probably including the new council of Fourty ${ }^{33}$. The harsh policy of Charles the Bold, who in his attempts to gain control over the Leiden ruling circle had chosen sides with its opponents, had in the end opposite effect.

The reconciliation of Hoeks and Kabeljauws was however not to last very long. Quarrels between both factions already came up in 1479 and resulted in a coup of Kabeljauws on the third of july. All leading Hoeks were exiled, leaving their families behind and suffering seizure of their possessions. Maximilian legalized the Kabeljauws assumption of power by granting them pardon for their actions. He nevertheless ordered the new magistrates to return the seized possessions to their rightful owners. This turned out to be a very long lasting procedure and lawsuits were brought forward initially at the Court of Holland and later on before the Grote Raad or Great Council at Malines ${ }^{34}$. In the meantime many Hoeks remained in exile and had no access to their possessions. Frustrations ran high and ended up in the treaty with the already mentioned condotierre van Broekhuizen and the attack on Leiden in january 1481.

After the siege and restoration of the Kabeljauws political power, Maximilian, who initially withdrew the privilege of the Council of Fourty, allowed its restoration a couple of months later. This time the list of members was made up by the sovereign himself. Vacancies were to be filled by co-optation. It put an end to all political ambitions of the Hoeks who were for years to come excluded from the town magistrate. Only at the close of the decade some Hoeks were allowed to participate in the daily administration, but they were only few ${ }^{35}$.

31. MARSILJE, Het financiële beleid, pp. 86-89. VAN GENT, Hoeken en Kabeljauwen in Leidem pp. 36-37.

32. A.G.JONGKEES, Het Groot Privilege van Holland en Zeeland (14 maart 1477), in W.P. BLOCKMANS, 1477. Het algemeen en de gewestelijke privilegiën van Maria van Bourgondië voor de Nederlanden (Standen en Landen LXXX), Kortrijk, 1985, p. 183.

33. VAN GENT, Hoeken en Kabeljauwen in Leiden, pp. 38-39.

34. Ibidem, pp. 41-43.

35. VAN GENT, De Hoekse factie in Leiden, pp. 136-140. 
The very difficult financial situation in Leiden, partly caused by the economic depression and unfortunate mint policy of Maximilian, posed about 1500 a severe threat to the urban autonomy. In 1496 Philip the Fair took farreaching measurements to reorganize the city finances. He ordered extension of payment of all debts, the levying of new taxes and a property tax of $1 \%$ among all inhabitants. Officials from the central government were put in charge of the operation, but initially all competencies of the magistrates remained unchallenged. In 1504 it became clear that the goals of the reorganization were not met. According to Blok, the magistrate was blamed for this failure. The duke cancelled the privilege of Fourty and nomination rights of the vroedschap. Instead he nominated two burghomasters and two treasurers for a period of four years ${ }^{36}$. Also the remarkable continuity of names of the elected aldermen shows that the duke relied on experience and stability in order to solve the immense problems the city found itself in.

After the death of Philip the Fair in 1506, Maximilian, now tutor of the future Charles V,pursued the same policy. Onlyin 1510, when most problems seemed to be solved, the removed privileges were to a large extent restored. However Maximilian made some important provisions that allowed him to hold a strong grip on the structure of the town magistrate. He demanded that all members of the new council of fourty should also obtain a seat in the vroedschap. Since the vroedschap at that time hardly counted fourty members, the effect was that both councils almost completely overlapped ${ }^{37}$. In that way Maximilian constructed a political network, that almost entirely consisted of magistrates of his own choice.

\section{Conclusion}

As could be expected in the case of a rather smallscale town, with little influence on the surrounding countryside, Leiden was no real bastion against the centralizing policy of the Burgundians. In fact tensions between Hoeks and Kabeljauws offered the dukes several opportunities to interfere in city politics and mould it to their own needs. Despite several urban risings during the reign of Philip the Good, his position was never challenged. The Hoeks coup of 1481 posed a threat to the souvereign but by making use of military force he quite easily subdued the city and restored the balance of power. Through time the approach of the dukes altered. While Philip the Good remained to a large extent loyal to the Kabeljauws option, his son Charles took sides with the rivals of those in power and seemed to follow the pattern Elias propagated. Maximilian returned to the Kabeljauws option, especially when it turned out that the Hoeks faction posed a real threat to his position. Nonetheless, all dukes tried to establish a firm basis of

36. HAMAKER, Leiden in staat van faillissement, pp. 184-187. DOWNER, De financiële toestand, pp. 12-14. PJ. BLOK, Geschiedenis eener Hollandsche stad. II Eene Hollandsche stad onder de Bourgondisch-Oostenrijksche heerschappij, 's-Gravenhage, 1912, p. 113.

37. GAL. Secretarie archief I inv. 40. DE BOER, Die politische Elite, p. 96. 
supporters of their policy within the city by controlling to a large extent the nomination of aldermen and the structure of the council of Fourty. The worsened economic and financial situation in the city caused a farreaching intervention of Philip the Fair in city politics. Although his measures were softened by Maximilian later on, he nevertheless profited from the policy of his predecessor and maintained a firm grip on the town magistrate which almost consisted completely of loyal supporters. 